University of Rhode Island

DigitalCommons@URI

The Rhode Island Current Conditions Index

Economics

8-2005

\title{
Rhode Island Current Conditions Index - August 2005
}

Leonard Lardaro

University of Rhode Island, lardaro@uri.edu

Follow this and additional works at: https://digitalcommons.uri.edu/ricci

Part of the Econometrics Commons

Terms of Use

All rights reserved under copyright.

\section{Recommended Citation}

Lardaro, Leonard, "Rhode Island Current Conditions Index -- August 2005" (2005). The Rhode Island Current Conditions Index. Paper 99.

https://digitalcommons.uri.edu/ricci/99

This Article is brought to you for free and open access by the Economics at DigitalCommons@URI. It has been accepted for inclusion in The Rhode Island Current Conditions Index by an authorized administrator of DigitalCommons@URI.For more information, please contact digitalcommons-group@uri.edu. 


\section{BURRENT}
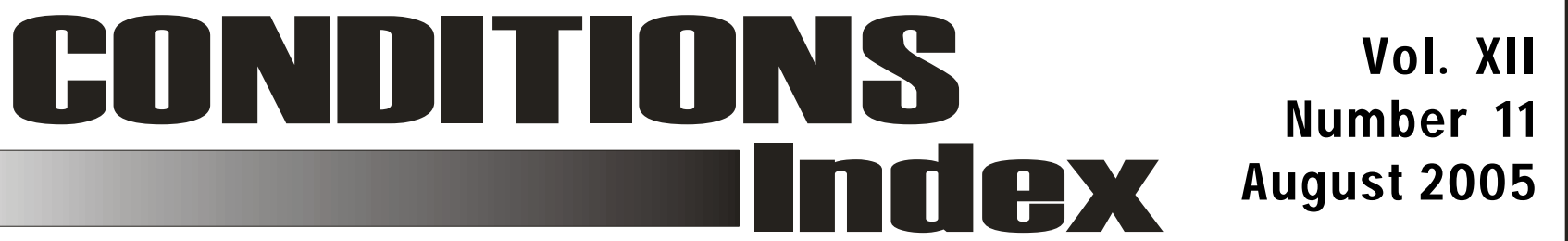

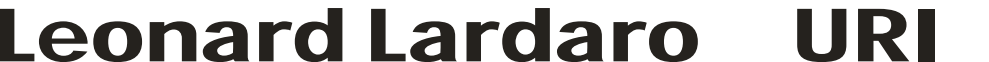 \\ \&OD}

The pace of economic activity in the third quarter continued to be moderate at best (translation: disappointing), especially after the jump in the pace of activity that occurred in June. The Current Conditions Index remained at 58 in August, as only seven indicators improved again this month. There was still good news to be found, though, in strong August performances by three $\mathrm{CCl}$ indicators: Retail Sales; the Labor Force; and Benefit Exhaustions. And, even though payroll employment fell on a month-to-month basis (by 600), this change, which was not statistically significant, was easily overshadowed by a two-percent rise in Resident Employment and a 6,400 increase in payroll employment - both on a yearover-year basis. Furthermore, the recent trend of a rising Labor Force accompanied by declines in both layoffs (New Claims) and long-term unemployment (Benefit

\begin{tabular}{lc}
\multicolumn{2}{c}{ CCI Indicators - \% Change } \\
Government Employment & 0.0 \\
US Consumer Sentiment & -6.9 \\
Single-Unit Permits & -10.2 \\
Retail Sales & $14.2 \mathrm{Y}$ \\
Help Wanted Advertising & $0.7 \mathrm{Y}$ \\
Priv. Serv-Prod Employment & $2.3 \mathrm{Y}$ \\
Man-Hours Manufacturing & -5.1 \\
Manufacturing Wage & $0.7 \mathrm{Y}$ \\
Labor Force & $2.1 \mathrm{Y}$ \\
Benefit Exhaustions & $-6.0 \mathrm{Y}$ \\
New Claims & $-2.9 \mathrm{Y}$ \\
Unemployment Rate & 2.0 \\
\multicolumn{1}{|c|}{$\mathbf{Y}=$ I mproved Value } &
\end{tabular}

Exhaustions), which points to the reversal several pressing economic concerns from last year, continued in August.

Retail Sales, which has been one of our strongest indicators for quite a while, rose sharply in August, by 14.2 percent, following a double-digit decline in July. Along with this was another drop in US Consumer Sentiment, 6.9 percent, its eighth decline in the last year. While the growth in labor demand, in terms of Help Wanted Advertising, slowed in August to 0.7 percent, layoffs, as measured by New Claims, declined by 2.9 percent, at the same time long-term unemployment, measured by Benefit Exhaustions, fell by a respectable 6 percent. August marked the third consecutive month for which both New Claims and Benefit Exhaustions improved, and only the fifth time that both have simultaneously improved over the past twelve months.

August saw a dramatic rise in our Labor Force $(+2.1 \%)$, which was almost twice July's growth rate and the sixth consecutive rise in this indicator, a very positive sign. While our Unemployment Rate rose slightly, by one-tenth of a percentage point, the fact that this occurred along with such a sharp rise in our Labor Force allows this to be more properly viewed as a neutral rather than a negative performance.

Government Employment was flat in August, remaining at approximately 66,000. Along with this, the growth in Private Service-Producing Employment remained at its recent high of 2.3 percent once again in August, matching the highest rate we had witnessed in the past year.

Economic weakness in August was concentrated in our manufacturing sector and new home construction. Manufacturing Man-hours slid by 5.1 percent compared to last August, which was among its most rapid rates of decline in the past year. And, while Manufacturing Wage growth improved to 0.7 percent in August, its level remains at only $\$ 13.11$, far below the national average. New home construction, as measured by Single-Unit Permits, fell by 10.2 percent in August, its eleventh decline in the last year.

This is the final report on the performance of Rhode Island's economy prior to Hurricanes Katrina and Rita. While Rhode Island did manage to pull out of its early year doldrums, and its economy has moved beyond a few troublesome structural issues from last year (declining Labor Force and Resident Employment), our state's economy is not moving forward with as much positive momentum as I would like to see in light of the after-effects of the hurricanes, most notably substantially higher energy prices. Rising interest rates and slowing housing momentum are also potentially troublesome trends. As federal spending rises sharply in the coming months to restore the Gulf Coast, it will provide a lift to the national economy. Let's hope that Rhode Island's economy also gets a substantial boost.

\section{CCl Over the Past 13 Months}

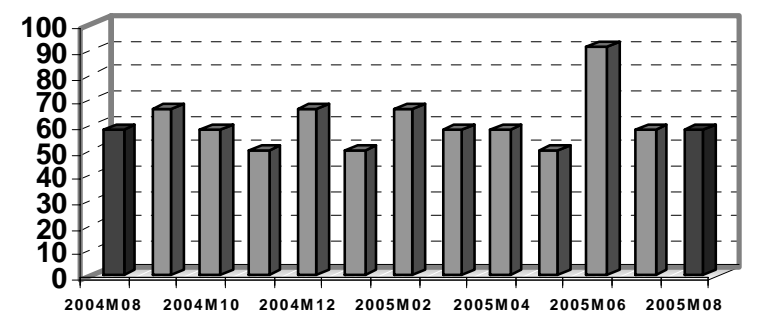

\begin{tabular}{|c|c|c|c|c|c|c|c|c|c|c|c|c|}
\hline & Jan & Feb & Mar & Apr & May & $J$ un & $\mathbf{J} \mathbf{u l}$ & Aug & Sep & Oct & Nov & Dec \\
\hline 2004 & 67 & 67 & 58 & 67 & 58 & 58 & 67 & 67 & 67 & 58 & 50 & 67 \\
\hline 2005 & 50 & 67 & 58 & 58 & 50 & 92 & 58 & 58 & & & & \\
\hline
\end{tabular}

